\title{
Estimation of emissions of volatile organic vapors from parameters measured in a fuel loading terminal
}

\author{
Eduard J. Krummenauer ${ }^{1}$, Elton G. Rossini ${ }^{1}$, José de Souza ${ }^{2}$, Alexandre Beluco ${ }^{3}$ \\ ${ }^{1}$ Universidade Estadual do Rio Grande do Sul (UERGS), Porto Alegre, RS, Brazil. \\ ${ }^{2}$ Fundação Liberato Salzano Vieira da Cunha, Novo Hamburgo, RS, Brazil. \\ ${ }^{3}$ Universidade Federal do Rio Grande do Sul (UFRGS), Porto Alegre, RS, Brazil.
}

Received 25 Aug. 2017; Received in revised form 6 Oct. 2017; Accepted 20 Oct. 2017; Available online 1 Mar. 2018

\begin{abstract}
In this work, an estimate of the emissions of volatile organic vapors emitted at a gasoline loading terminal is presented, in the absence of a vapor recovery unit. The estimation of the emissions is evaluated by the application of the General Law of Ideal Gases, using data measured in situations of fuel loading. A total of 3800 tank truck compartment samples were collected, totaling a loaded volume of 33161838 liters of gasoline for about 282 hours of operation in 21 days, or in three operating weeks. The results obtained provided a first estimate of the reduction of the environmental impact, evaluated by the reduction of the mass of evaporated gasoline and the registration in a database, for the execution of future projects.

Copyright $\mathbb{C} 2018$ International Energy and Environment Foundation - All rights reserved.
\end{abstract}

Keywords: Energy engineering; Organic vapors emissions; Non-renewable biomass; Fossil fuels.

\section{Introduction}

Volatile Organic Compounds (VOCs) are toxic substances that range from olefinic and aromatic hydrocarbons to other substances that contain oxygen, nitrogen, halogen and sulfur atoms in their molecular structure [1]. These compounds are a serious problem for large urban centers, where there is a large concentration of industries, as these are the largest VOCs in various forms. According to the Environmetal Protection Agency (EPA), volatile organic compounds are any compounds that participate in photochemical reactions in the atmosphere [2]. The emissions of these pollutants vary according to the sources or activities [3], their effects are studied in several documents and researches [4], [5], ranging from morphological changes in plants [6] to effects in humans [7], [8][1]. Ozone, formed at low altitudes, is a pollutant found in large urban centers, being formed by the photochemical reaction between oxides of nitrogen (NOx) and volatile organic compounds (VOCs). Solar radiation is the agent that initiates and maintains the photochemical cycle, the ozone formation is increased in high pressure systems, strong solar insolation and high VOC / NOx ratio [5]. Therefore, the emission of VOCs is associated with technologies applied on a large scale, such as the burning of fossil fuels, responsible for the formation of smog.

One of the fossil fuels that emits VOCs is gasoline. Gasoline is a product with a high degree of complexity, related to its manufacturing process, its raw material (Oil API grade that generated it) and its performance specifications. Its performance as a fuel is determined through its volatility, combustion quality and stability. The specifications vary in different countries, obeying the current legislation. For example, in the 
United States, gasoline is regulated by ASTM D-4814 and also by the Environmental Protection Agency (EPA). Some countries have more stringent legislation on the levels of aromatics and benzene in gasoline, for example in the European Union, where the limit of aromatics from 2005 was set at $35 \%$ of volume and benzene at $1 \%$ volume [9]. The compounds are added to the gasoline for different purposes. Primarily, oxygenates are added to increase octane and increase fuel efficiency. The additives are colorants with antidetonating properties, anti-oxidants and corrosion inhibitors, among others, which can provide greater safety and increase the life of the engines, having a very low concentration in volume, which can reach $0.1 \%$ of volume [10], [11]. Of the compounds added to gasoline, the one with the highest incidence in the world is methyl tert-butyl ether, also known as MTBE, it has high combustion quality and high volatility making it attractive in different markets. In the United States, the addition of this compound is regulated by the EPA, and may be added in a maximum content of $15 \%$ by volume. There is also the addition of anhydrous ethanol in the maximum of $15 \%$ in the US fuel market, which is currently the largest consumer market of the product.

In Brazil, the production of commercial gasoline, Gasoline $\mathrm{C}$, is mixed with oxygenated compounds, such as alcohols and ethers, its use is mainly due to the similarity in the quality of combustion and volatility with gasoline. Automotive commercial gasoline is basically composed of paraffins, olefins, aromatics and naphthenic [12]. The oxygenated compound most commonly used in gasoline is anhydrous ethanol that normally varies its composition according to the sugarcane harvesting periods, the largest raw material in the country for the production of this fuel. Currently, the blend is $80 \%$ gasoline and $20 \%$ anhydrous ethanol. The use of ethanol is advantageous mainly by the reduction of pollutants in the atmosphere, since it is a fuel of renewable source and with emission of pollutants less aggressive than the petroleum products in general. The National Agency for Petroleum, Natural Gas and Biofuels -ANP is the regulatory body for the technical specifications of gasoline and other petroleum products. Through ANP Ordinance No. 57 of 10/20/2011 [13] and the ANP Technical Regulation No. 7/2011 [14], the regulations for the commercialization of these compounds were established. The maximum olefins and aromatic contents were defined as $30 \%$ and $45 \%$ respectively and the maximum benzene content is $1 \%$ of the total volume for $\mathrm{C}$ (commercial) petrol and $1.5 \%$ of the volume for premium grade petrol.

Gasoline emission limits vary according to current legislation. In the European Union they were set at $35 \mathrm{~g}$ VOC per cubic meter of loaded fuel. At the same time Germany adopted a much more stringent standard, limiting the emission to only $0.15 \mathrm{~g}$ of VOC per cubic meter. The United States has set a limit of $10 \mathrm{~g}$ of VOC per cubic meter of loaded fuel [15].

The process of loading in tank trucks requires the control of measured parameters related to the properties of gasoline. Volatility is a property that characterizes the tendency of the compound to change from liquid state to gaseous state, having a direct influence on fugitive emissions and mass losses in fuel loading. This trend is specified by two tests: ASTM Distillation (ASTM D-86 [16]) to determine the gasoline distillation curve. The Reid Vapor Pressure, PVR, is the vapor pressure specification at $100^{\circ} \mathrm{F}\left(37.8^{\circ} \mathrm{C}\right)$. This property is used as a model for the standardization of fuel quality, since the vapor pressure directly affects the performance of combustion engines. PVR is studied in blends [17][11], covering the mixture of several percentages of oxygenates, as real options for altering the volatility of the final product. Basically, ethanol, which is the most used compound in Brazil, increases the PVR of commercially sold gasoline, especially when there is an addition of values lower than $5 \%$ of the total volume, decreasing this effect with the increase of the mixture. To better characterize, an increase in PVR means a real increase in the tendency of the fuel to go into the gaseous state [10]. In Brazil, the Reid vapor pressure value is normalized by NBR 14149 Error! Reference source not found., and sets the maximum value for the pressure at $69 \mathrm{kPa}$. The Reid vapor pressure measurement method is described by standard (ASTM D-323 [19][18]). The vapor pressure, also called true vapor pressure, can be defined as the pressure at which there is equilibrium between the liquid phase and the vapor phase of any substance API (1997). Temperature and composition are the terms of greatest influence on vapor pressure.

The process of loading fuel into terminals, daily move millions of liters of gasoline. This process involves fuel evaporative and VOC emissions. Charging techniques were developed for fuel utilization. In the terminal located in the city of Esteio, metropolitan region of Porto Alegre, in the state of Rio Grande do Sul, reaches 3500000 liters per day. The loading process used in the Terminal under study, is characterized as botton loading. In this method, shown in Figure 1, the inlet pipe is installed in the bottom of the cargo tank and the turbulence is minimized, reducing the formation of vapors compared to other loading techniques, such as top loading. 


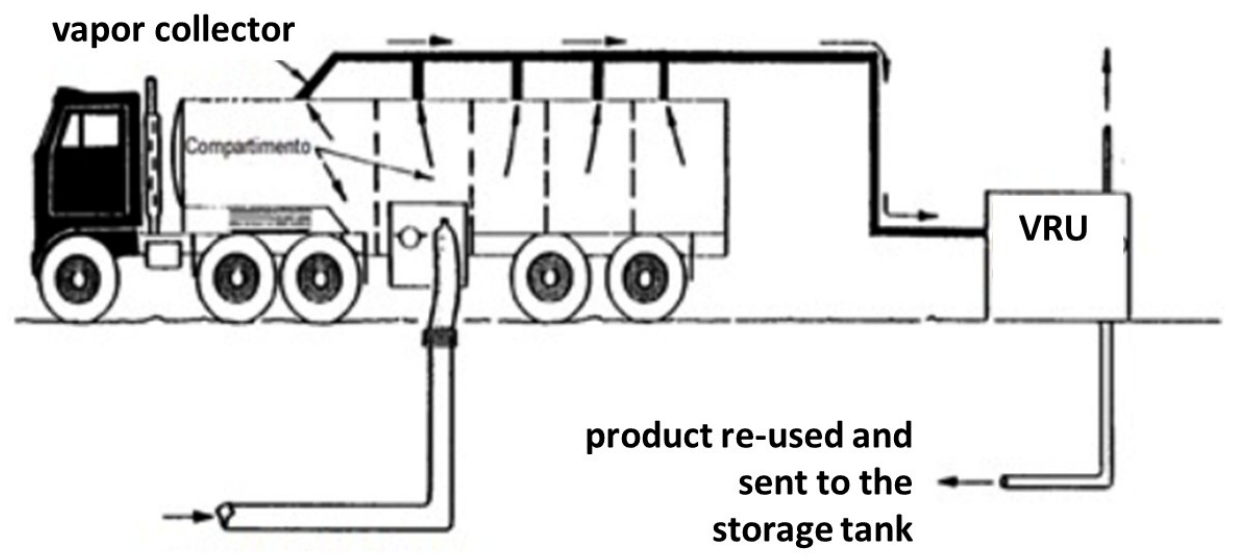

product entry into the truck

Figure 1. Tank truck and its parts of the process. (Adapted from Ref.[2].)

Vapors formed during the charging process should be reused. To this end, a vapor trap system is designed, located at the top of the tank truck. The nozzle sealing caps of the trucks are opened and the captive pipeline for conveying the gaseous mixture of air and hydrocarbons to the entrance of the Vapor Recovery Unit, VRU, is installed. The VRU uses activated carbon adsorption technology and has the function of reducing the emission of hydrocarbons from the handling and transportation of fuels. This technology has efficiency close to $99 \%$, but activated carbon has limited adsorption capacity, requiring regeneration or desorption [20]. To reduce hydrocarbon emissions, in a technical and economically feasible way, the VRU has two vessels with activated carbon filters, two vacuum pumps, an absorption tower and monitoring instruments. Often also the current generated in the vacuum desorption process is directed to an absorption process for the recovery of the desired compounds. In the process characterized as absorption, the stream of the gas to be absorbed is introduced into a chamber where it is mixed with an absorber liquid. The vapor then passes into the liquid phase and the unabsorbed quantity obeys the Henry's Law, which can be defined as the dissolved fraction of a gas / vapor in an absorber liquid is proportional to the gas pressure above the liquid [8]. According to Ref. [21], the absorption can reach efficiency values in the order of $98 \%$ and it is due to this efficiency that most of the vapor recovery systems use the absorption technique either as single process or combined with other processes to improve Efficiency.

In the VRU, the gas mixture crosses the adsorption vessel containing the activated carbon filter, where the hydrocarbons are adsorbed. After passing through the activated carbon filter, the gaseous mixture is conducted to the exit of the unit, vent, and released into the atmosphere at acceptable concentration levels. At the VRU, a process of cleaning activated carbon filters occurs. In this way, one of the two filters will be available to filter the gas mixture from the terminal. In this process, called the regeneration process the activated carbon vessel is isolated and subjected to negative pressures of the order of $-0.950 \mathrm{kgf} / \mathrm{cm}^{2}$, by the activation of vacuum pumps. In addition to the negative pressure, a controlled flow of clean air is permitted for a period of time equivalent to $25 \%$ of the regeneration cycle time of the carbon filter, which is $15 \mathrm{~min}$. The air requirement for removal of the remaining hydrocarbons is adjusted during field testing and integrated with the programmable logic controller software, PLC.

This work presents an estimate of the atmospheric emissions of organic vapors, VOCs, through the analysis of data measured at the loading terminal of a company that operates in fuel distribution.

\section{Methodology}

The efficiency of the VRU is calculated by comparing the incoming and outgoing masses of the vapor recovery unit (Figure 2). A method for determining the mass of hydrocarbons is based on the laboratory analysis, carried out from the sampling of the gases in and out of the unit. Another method for obtaining the mass values of hydrocarbons is from the flow measurements of the gaseous mixture of air and hydrocarbons and the concentration of the hydrocarbons in the mixture. In any case, the measurements and the experimental system follow specific methodologies. Information on VRU performance tests is described by the EPA.

In this work, the emission estimation on product loading is performed by calculating the volume variation. Therefore, the volume of liquid recovered at the output of the return pump is subtracting from the injection 
volume of the supply pump. For this calculation, data measured at the input and output of the unit, as well as data that is supported by the system for absorption (not steam) is required. The procedure allows to determine the minimum efficiency of the process.

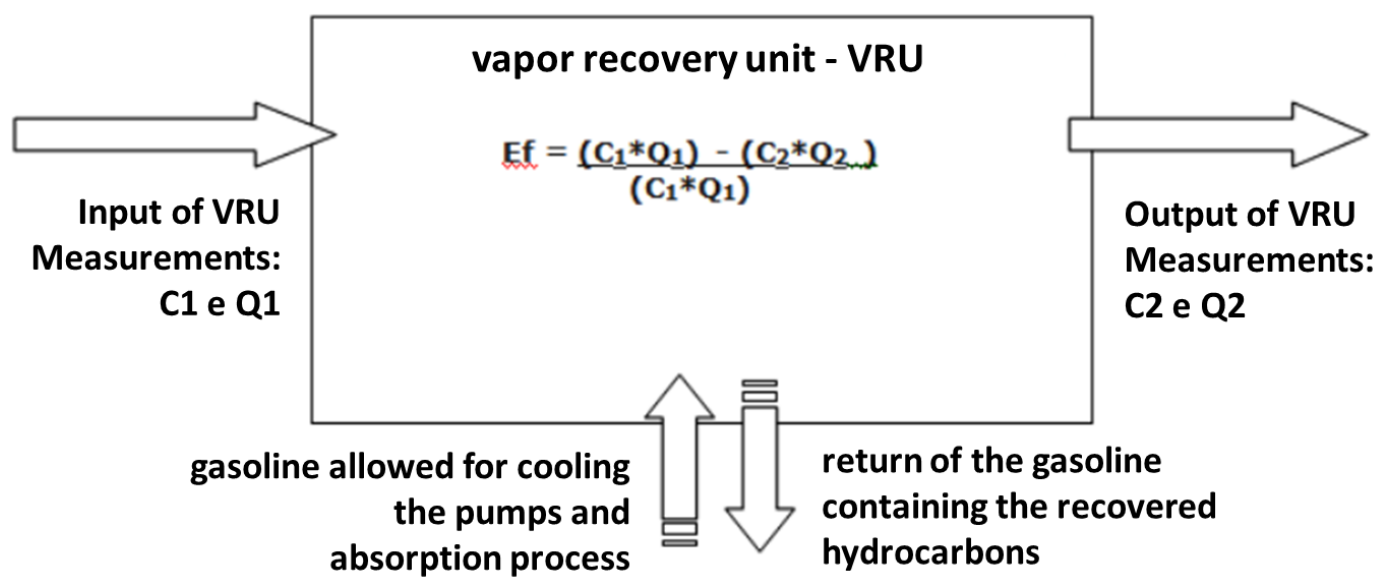

Figure 2. Method for calculating the efficiency of the VRU.

The gas vapor mass in the vapor phase, in $\mathrm{g}$, is obtained by applying the Ideal Gas Law,

$\mathrm{m}=\frac{\mathrm{VMP}}{\mathrm{RT}}$

where $\mathrm{V}$ is the volume recovered, in $\mathrm{L} ; \mathrm{M}$ is the average molecular weight of the vapors, in $\mathrm{g} / \mathrm{mol}$; $\mathrm{P}$ is the vapor pressure, calculated in psia and converted to atm; ; $R$ is the gas constant, equal to $0.082 \mathrm{~L} . \mathrm{atm} /$ $\mathrm{K} . \mathrm{mol}$; $\mathrm{T}$ is the absolute temperature of gasoline, measured $\mathrm{oC}$ and converted to $\mathrm{K}$.

The vapor pressure is calculated by equation (X), proposed by Ref. [22].

$$
\begin{gathered}
P=\exp \left\{\left[0.7553-\left(\frac{413}{T^{* \prime}+459.6}\right)\right] S^{0.5} \log (P V R)-\left[1.854-\left(\frac{1042}{T^{\prime \prime}+459.6}\right)\right] S^{0.5}\right\} \times \\
\exp \left\{+\left[\left(\frac{2416}{T^{*}+459.6}\right)-2.013\right] \log (P V R)-\left(\frac{8742}{T^{*}+459.6}\right)+15.64\right\}
\end{gathered}
$$

where $\mathrm{P}$ is the vapor pressure in psia; $\mathrm{T}$ is the temperature of the loaded product, measured in oF, PVR is the vapor pressure Reid, in psi and S is slope of the evaporated 10\% ASTM distillation curve, considered equal to 3 .

The following simplifying assumptions were applied: (1) the behavior of the gases described by the General Law of Ideal Gases; (2) non-monitoring of molar mass variation of gasoline; (3) gas-filled compartments have been found to be free of prior compounds; (4) true vapor pressure calculated by the equation based on the behavior of gasoline type A; (4) Use only one gas sample to check the Reid vapor pressure of the substance, due to the cost of each sample.

The main advantages of the adopted procedure are: (1) to obtain a simplified estimate of the minimum efficiency of the VRU, using data measured at a gasoline loading terminal; (2) to obtain a low cost estimate of organic vapor emissions from measured values. These low cost estimates provide an ideal parameter of behavior and estimates of minimum efficiency of the VRU process and maximum VOC emission.

\section{Results and analysis}

The load is programmed and executed by an automation system that employs a specific software. Thus, the process variables are measured, monitored and recorded by the software of the terminal load automation system.

This program has the objective of leasing customer orders on tank trucks and authorizes each truck from 
the entrance to the terminal to the printing of electronic invoices. It manages all the products injected into the compartments of the trucks, from the fuel, through the additives and individual markers of each product. An example is the addition of biodiesel in the correct ratio in each compartment.

The report generated through automation software contains the exact volumes injected into each tank as well as the temperature of the material at the time of entry into the tank. Table 1 presents a portion of the report issued.

Table 1. Samples collected to estimate emissions.

\begin{tabular}{llll}
\hline Hora $(\mathrm{xx}: \mathrm{xx})$ & Placa CT & Volume $(\mathrm{L})$ & Temperatura $\left({ }^{\circ} \mathrm{C}\right)$ \\
\hline $3: 43$ & IMG8836 & 4997 & 23,5 \\
$3: 49$ & IQZ8050 & 24000 & 23,5 \\
$3: 57$ & IMG8836 & 4997 & 23,5 \\
$4: 01$ & IMG8836 & 5000 & 23,5 \\
$4: 05$ & IFA0222 & 6000 & 23,5 \\
\hline
\end{tabular}

The software records the fuel input volumes in the absorption tower and the volumes at the output tower. The difference between these volumes is calculated and recorded, providing the recovered values of hydrocarbons. Table 2 presents the collection data and the closing times of the analysis. The records were separated into groups of seven days. Data collection was completed at different times in the afternoon and it was not possible to follow up the process in the 24 hours a day. The total volumes retrieved by the VRU from the terminal were recorded by the management software counter. The last row of the table shows the records of total time differences and total volumes recovered over the seven days. A total of 3,795 data were measured in different compartments, totaling a loaded volume of $33161838 \mathrm{~L}$ of gasoline in $281 \mathrm{~h}$ 51 min of operation in 21 days. The average operating temperature was approximately $26^{\circ} \mathrm{C}$. The total volume recovered and accounted for by the vapor recovery unit was $46,970 \mathrm{~L}$ of hydrocarbons.

Table 2. Recovered volume data.

\begin{tabular}{|c|c|c|c|c|c|}
\hline \multicolumn{2}{|c|}{ SEMANA 1} & \multicolumn{2}{|c|}{ SEMANA 2} & \multicolumn{2}{|c|}{ SEMANA 3} \\
\hline $\begin{array}{l}\text { Início: 00:00 } \\
\text { Final: (xx:xx) }\end{array}$ & $\begin{array}{l}\text { Recuperado } \\
\text { Vol. (L) }\end{array}$ & $\begin{array}{l}\text { Início: 00:00 } \\
\text { Final: (xx:xx) }\end{array}$ & $\begin{array}{l}\text { Recuperado } \\
\text { Vol. (L) }\end{array}$ & $\begin{array}{l}\text { Início: 00:00 } \\
\text { Final: (xx:xx) }\end{array}$ & $\begin{array}{l}\text { Recuperado } \\
\text { Vol. (L) }\end{array}$ \\
\hline 13:00 & 2285 & $13: 25$ & 2500 & $13: 27$ & 1749 \\
\hline 13:00 & 2083 & $13: 34$ & 2644 & $14: 00$ & 4171 \\
\hline 13:05 & 2040 & $12: 32$ & 2091 & $13: 00$ & 2114 \\
\hline $13: 30$ & 2172 & $13: 05$ & 2054 & $13: 00$ & 2052 \\
\hline $13: 35$ & 2276 & $13: 22$ & 2148 & $13: 42$ & 1695 \\
\hline $13: 19$ & 2511 & $12: 28$ & 1363 & $13: 40$ & 2076 \\
\hline $13: 33$ & 2704 & $13: 34$ & 1862 & $16: 00$ & 2380 \\
\hline 2:02 & 16071 & 3:00 & 14662 & $5: 49$ & 16237 \\
\hline
\end{tabular}

The vapor pressure, $\mathrm{P}$, was calculated by equation (2). Table 3 shows some calculated values and the time at which measurements were taken. A constant temperature variation is observed at similar times, as in the loading terminal used for the evaluation there are 5 loading islands and the time of product stoppage in the pipeline directly influences the temperature of the product. The same value for Reid vapor pressure, PVR $=9.43$ psia, was considered. This value was obtained through a laboratory analysis.

Table 3. Calculated values for the vapor pressure.

\begin{tabular}{llll}
\hline Hora $($ xx:xx $)$ & Volume $(L)$ & Temperatura $\left({ }^{\circ} \mathrm{C}\right)$ & Pressão de Vapor $($ psia $)$ \\
\hline $03: 39$ & 4999 & 23,5 & 6,38 \\
$03: 39$ & 4997 & 23,1 & 6,29 \\
$03: 43$ & 4998 & 23,4 & 6,36 \\
$03: 43$ & 4997 & 23,5 & 6,38 \\
\hline
\end{tabular}


The pressure values served as input data to estimate the mass loss of each load, through equation (1). The estimate of the total mass of evaporated product, in the period of 21 days, was $41741 \mathrm{~kg}$, in a volume of $55286 \mathrm{~L}$ of gasoline. Table 4 shows a sample of the calculated results.

Table 4. Data used for mass loss calculation.

\begin{tabular}{llllll}
\hline $\begin{array}{l}\text { Hora } \\
(\mathrm{xx}: \mathrm{xx})\end{array}$ & Volume (L) & $\begin{array}{l}\text { Temperatura } \\
\left({ }^{\circ} \mathrm{C}\right)\end{array}$ & $\begin{array}{l}\text { Massa Molecular } \\
\text { Média, M (g) }\end{array}$ & $\begin{array}{l}\text { Pressão de } \\
\text { Vapor, P (atm) }\end{array}$ & $\begin{array}{l}\text { Massa de Gasolina } \\
\text { na Fase Vapor m }(\mathrm{g})\end{array}$ \\
\hline $02: 15$ & 4998 & 23,3 & 66 & 0,4307 & 5841 \\
$02: 33$ & 5000 & 22,9 & 66 & 0,4250 & 5774 \\
$02: 41$ & 4998 & 23,2 & 66 & 0,4293 & 5824 \\
\hline
\end{tabular}

The volume of condensed product in the steam recovery unit was used the PLC data. Figure 3 shows a representation of the VRU supervisory screen. In the circle in red stand out the daily reuse data of gasoline, these data are counted from 00:00 hours and are shown in the supervisory.

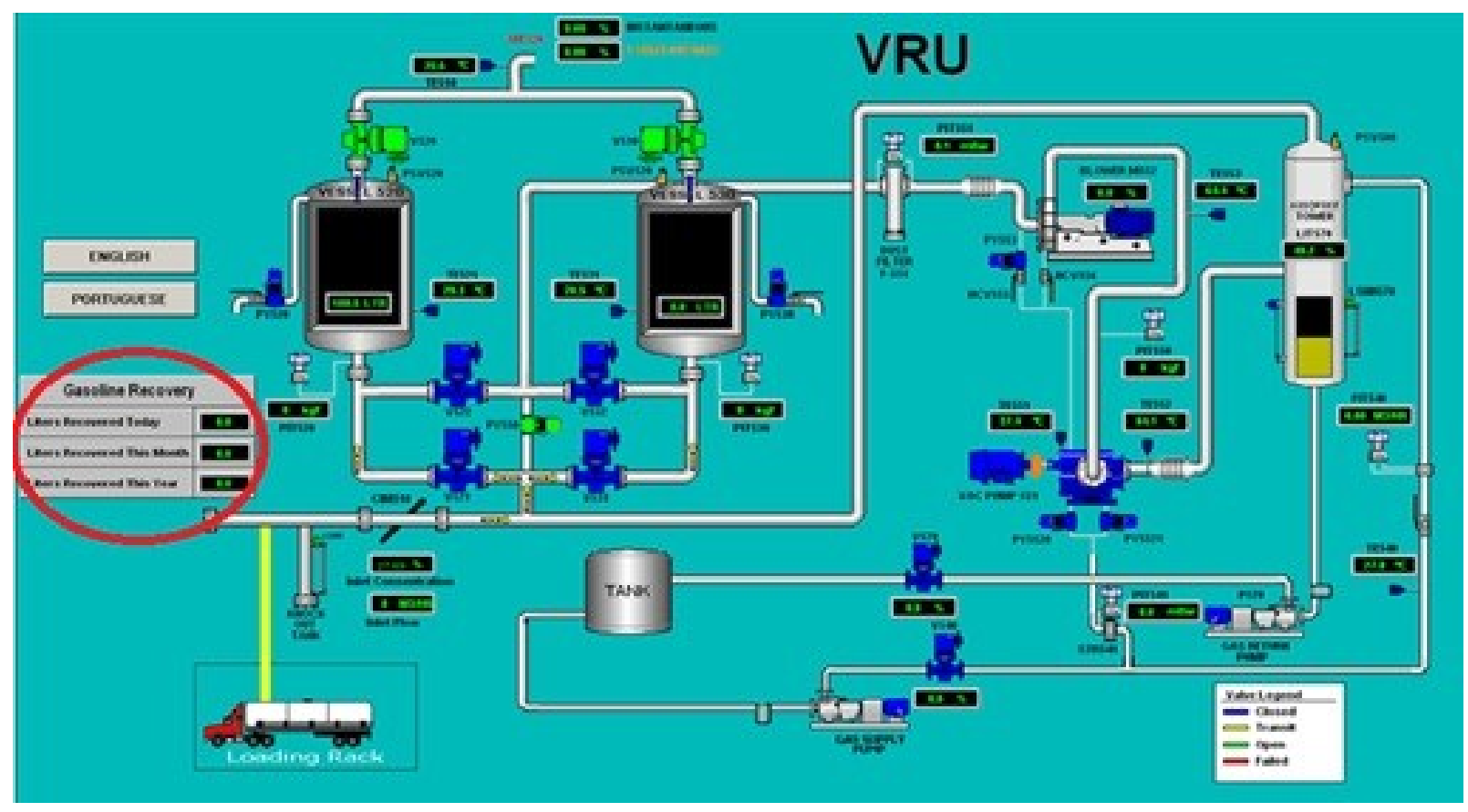

Figure 3. Supervisory for the vapor recovery unit.

\section{Conclusions}

This work presented an estimate of the evaporated products that would be emitted to the atmosphere if a vapor recovery unit were not installed.

The results demonstrated a significant energy recovery and a significant reduction of environmental impact. In 21 days, or 3 operational weeks, the estimated reuse was approximately 47,000 L of fuel. The estimate was $55,000 \mathrm{~L}$ of evaporated fuel, considering that the gasoline density is $0.755 \mathrm{~kg} / \mathrm{m}^{3}$. The efficiency of the Vapor Recovery Unit was approximately $85 \%$.

There is considerable imprecision in the results, which is due to the use of simplifying hypotheses, such as determining the estimated gas mass evaporated by applying the Ideal Gas Law, without correction factors; And the use of gasoline A, which has a different composition from gasoline $\mathrm{C}$.

Estimates can be improved by considering correction factors for gasoline in the measurement period. As a continuity perspective, it is proposed to apply the following corrections: to establish estimates for the variation of the molar mass of the gasoline that has constant variation due its production; the calculation of the true vapor pressure of the gasoline used in the collection period, composed of $80 \%$ of gasoline A and $20 \%$ of anhydrous ethanol; and the use of correction factors in the ideal gas law to better represent the properties and conditions of gasoline $\mathrm{C}$. 


\section{References}

[1] HUNTER, P., OYAMA; S.T. (2000) The Problem of Volatile Organic Compounds - Control of Volatile Organic Compound Emissions. New York: Jonh Wiley \& Sons.

[2] EPA - ENVIRONMENTAL PROTECTION AGENCY (1995) Compilation of Air Pollutant Emission Factors. Petroleum Industry. AP-42, $5^{\circ}$ Edição.

[3] API - AMERICAN PETROLEUM INSTITUTE (1997) Technical Data Book.

[4] CETESB (2003) Ar - Qualidade do ar. Disponível em: <http://www.cetesb.sp.gov.br/Ar>.

[5] PERRY, R. H., GREEN, D. (2007) Chemical Engineers' Handbook. 8th Ed. New York: McGrawHill.

[6] LIMA, J.S., Bioindicação, Biomonitoramento: Aspectos Bioquímicos e Morfológicos. Techoje. $<$ http://www.techoje.com.br/meioambiente $>$.

[7] CONCAWE (1992) Gasolines. Report 92/103. Brussels. Disponível em: <http://www.concawe.be >.

[8] CONCAWE (1999) Best available techniques to reduce emissions from refineries. Report 99/01. Brussels. Disponível em: http://www.concawe.be

[9] GAUTAM, R., BOGDAN, P., LICHTSCHEIDL, J. (1999) Maximize use of existing assets through advances in CCRTM reforming catalysts. In: EUROPEAN REFINING TECHNOLOGY CONFERENCE, Paris.

[10] CPS - the college of petroleum and energy studies (2001) The Technology of Gasoline and Diesel Fuel. Oxford.

[11] CRUZ, M. J. F.; CARVALHO, F. R.; STRAGEVITCH, L. (2003) Efeito de aditivos oxigenados na pressão de vapor de gasolinas. In: CONGRESSO BRASILEIRO DE P\&D EM PETRÓLEO E GÁS, 2., 2003, Rio de Janeiro. Anais ... Rio de Janeiro: UFRJ.

[12] PETROBRAS (1996) Gasolina Automotiva. Betim: ASCOM. 90p.

[13] Petroleum National Agency, ANP. Ordinance n.57, Oct 20, 2011. Available in https://www.legisweb.com.br/legislacao/?id=115466. Accessed on Aug 25, 2017.

[14] Petroleum National Agency, ANP. Technical Regulation n.7, February, 9. Available in http://www.udop.com.br/download/legislacao/comercializacao/institucional_site_juridico/ res_anp_07_amplia_nomenclatura_alcool.pdf. Accessed on Aug 25, 2017.

[15] PEZ̄OLT, D.J.; COLLLICK, S.J.; JÖHNSON, H.A.; ROBBINS, L.A. (1997) Pressure swing adsorption for VOC recovery at gasoline loading terminals. Environmental-Progress. v.16, n.1, p. 16-19.

[16] ASTM D86, Standard Test Method for Distillation of Petroleum Products and Liquid Fuels at Atmospheric Pressure. Available in https://www.astm.org/Standards/D86.htm. Accessed on Aug 25, 2017.

[17] PUMPHREY, J. A.; BRAND, J. I.; SCHELLER, W.A. (2000) Vapour pressure measurements and predictions for alcool-gasoline blends. Fuel. V.79, p.1405-1411.

[18] NBR 14.149:2017, Norma Técnica para Gasolina e misturas de gasolina com produtos oxigenados, Determinação da pressão de vapor, Método seco. Available in http://www.abntcatalogo.com.br/norma.aspx?ID=369812. Accessed on Aug 25, 2017.

[19] ASTM D323, Standard Test Method for Vapor Pressure of Petroleum Products (Reid Method). Available in https://www.astm.org/Standards/D323.htm. Accessed on Aug 25, 2017.

[20] CONCAWE (2002) VOC emissions from loading gasoline onto sea-going tankers in EU-15: control technology and cost-effectiveness. Report No. 6/02. Brussels. Disponível em: $<$ http://www.concawe.be $>$.

[21] PURCELL, R.Y.; SHAREEF, G.S. (1986) Control Technologies for Hazardous Air Pollutants. USEPA, Research Triangle Park, NC, pp. 24, 75-80.

[22] API - AMERICAN PETROLEUM INSTITUTE (1983) Technical Data Book. 


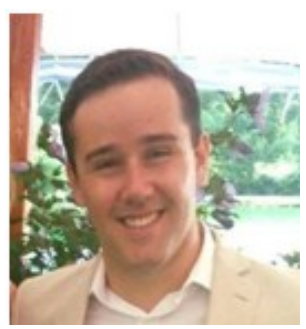

Eduard J. Krummenauer is an energy and sustainable development engineer since 2011 graduated from the State University of Rio Grande do Sul. He has experience in oil and gas and is currently infrastructure manager for Latin America GLD.

E-mail address: ejkrummenauer@gmail.com

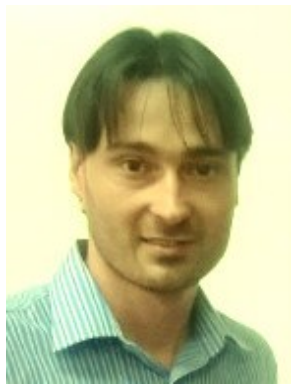

José de Souza is a Professor of the Liberato Salzano Vieira da Cunha Technical School Foundation (FETLSVC) in Novo Hamburgo, southern Brazil. He has directed more than thirty projects for scientific and technological development. He completed his Master's degree in Engineering at the Federal University of Rio Grande do Sul (UFRGS) in 2010, and obtained his Doctor's degree in Engineering also at UFRGS in 2016. He has worked on projects for generating biogas from agriculture waste. He has over 100 papers in conferences and scientific journals and he is a reviewer for scientific journals. $\mathrm{He}$ is a founder of the Brazilian Association of Biogas and Methane.

E-mail address: josesouza@liberato.com.br

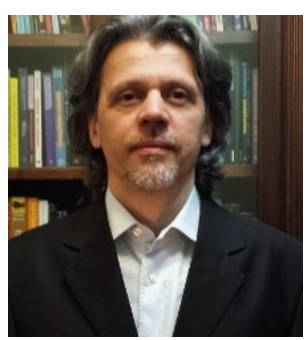

Elton G. Rossini is a Professor in the field of renewable energy at the Universidade Estadual do Rio Grande do Sul (UERGS). He received his Master in Engineering and his Doctorate in Engineering degrees from Universidade Federal do Rio Grande do Sul (UFRGS). He has experience in solar radiation measurements and solar energy technologies. His research interests include energy audit, renewable energy resource potential and renewable energy technologies.

E-mail address: elton-rossini@uergs.edu.br

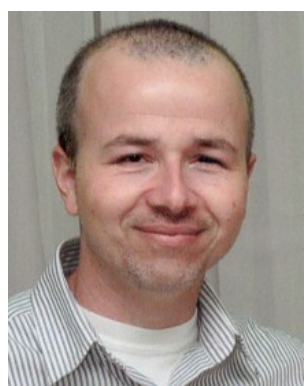

Alexandre Beluco is Doctor of Engineering, Civil Engineering and BS in Physics, and is a professor at the Institute of Hydraulic Research (IPH), UFRGS, and has activity as a researcher on renewable energy resources. He teaches courses on electricity and on design methods for undergraduate engineering and on design of experiments and on design methods for the graduation course in water resources, for which also offers elective courses on natural resources and renewable energy. Currently, he serves as reviewer of Energy, Solar Energy and Renewable and Sustainable Energy Reviews and had two papers recently cited by Renewable Energy Global Innovations.

E-mail address: albeluco@iph.ufrgs.br 